Article

\title{
A New Look at the Natural Capital Concept: Approaches, Structure, and Evaluation Procedure
}

\author{
Margarita Ignatyeva ${ }^{1,2}$, Vera Yurak $1,2, * \mathbb{D}$ and Oksana Logvinenko ${ }^{3}$ \\ 1 Research Laboratory of Disturbed Lands' and Technogenic Objects' Reclamation, \\ Ural State Mining University, 620144 Yekaterinburg, Russia; rinis@mail.ru \\ 2 Center for Nature Management and Geoecology, Institute of Economics, The Ural Branch of Russian \\ Academy of Sciences, 620014 Yekaterinburg, Russia \\ 3 Department of Economics and Management, Ural State Mining University, 620144 Yekaterinburg, Russia; \\ ief.etp@ursmu.ru \\ * Correspondence: vera_yurak@mail.ru; Tel.: +7-343-278-7385
}

Received: 24 September 2020; Accepted: 27 October 2020; Published: 6 November 2020

check for updates

\begin{abstract}
This article considers the concept of natural capital as a basic construct of sustainable development. However, after numerous studies, a number of aspects of accounting and valuation of natural capital remain unspecified. The relevance and imperfection of the guidelines used to assess natural capital make relevant the development of such issues as the conceptual apparatus and methods to natural capital assessment. Therefore, the core objectives of the paper are: (1) to substantiate the structure of natural capital, taking into account the natural resources and ecosystem approaches; (2) to clarify the concepts of "function" and "services" in relation to abiotic and biotic components of the environment; (3) to generalize and analyze the classifications of ecosystem services, and to develop the authors' classification; (4) to identify the most common methods for the economic assessment of natural capital's components, and to implement these methods within a specific territory. These methods have been tested on the Khanty-Mansi Autonomous Okrug (KhMAD, Russia). The most typical ecosystems of the region and their inherent ecosystem services have been identified. Assessment results are presented for (1) forest ecosystems, (2) mountain ecosystems, and (3) ecosystems of swamps, lakes, and rivers.
\end{abstract}

Keywords: natural capital; abiotic and biotic components; ecosystems; ecosystem services and functions; economic assessment

\section{Introduction}

The socioeconomic development of a territory is largely determined by the presence and degree of usage of the economic potential, which includes lower-order potentials: production, labor, innovation, natural, etc. Moreover, the natural potential is considered as a kind of locomotive in relation to the rest [1,2]. Ongoing evolution of the natural potential led to the creation of a new concept called natural capital [3]. There is no doubt that the valuation of natural capital of a specific territory is a necessary condition for the creation of investment attractiveness. However, the development of natural potential should be conducted according to the principles of rational use [4,5]. Research [6,7] shows that the rational use of natural resources requires the timeliness and completeness of their accounting (availability, depletion, reproduction, etc.). Nowadays, in connection with the increasing mass of waste [8], the problem of accounting for production and consumption waste $[9,10]$, including mature and ownerless waste $[11,12]$, is on the agenda $[13,14]$. Even though accounting in physical units does not cause problems, assessment in value units remains unresolved [6], although the experience of assessing the natural resource potential of individual territories_and, in recent years, regional natural 
capital-takes place both in foreign and Russian practice [15-26]. Moreover, studies and practices exist for measuring and analyzing the natural capital in accountancy systems [27]. For instance, the UK and the Netherlands are the pioneers in the introduction of ecosystem accounting to the System of Environmental Economic Accounting [28]. However, the different approaches—for instance, based on 'exchange values' and 'three tiers for biodiversity accounting' (guidance provided by the Convention on Biological Diversity in 2006) —and aspects of exclusion of double accounting still incorporate many questions and uncertainties [29], such as: what ecosystem services should we exclude from the accounting of natural capital, and how can some benefits be differentiated by excluding one of the ecosystem services being assessed (this has a close link to the understanding of what ecosystem functions and ecosystem services are, as well as the question of whether should we monetize the functions (supporting ecosystem services) or not)? Where are the guidelines for assessing natural capital in the context of different climatic zones or physical and geographical ones? What are the exact criteria for dividing ecosystems for a subsequent evaluation of the natural capital?-and many, many others. In addition, economic valuation issues are complicated by the existence of multiple approaches to natural capital $[30,31]$. However, after numerous studies on the theoretical and methodological foundations of ecological economics [32-35], a number of aspects of accounting and valuation of natural capital remain unspecified [36-38]. The novelty of the problem (the appearance of which occurred in the middle of the twentieth century) and the relevance and imperfection of the guidelines used to assess natural capital make relevant the development of such issues as the conceptual apparatus and methods for natural capital's assessment.

Hence, the aim of this study is to develop the theoretical and methodological foundations of natural capital, which predetermine the refinement of the methods and guidelines of natural capital's economic assessment. Therefore, the objectives of the study are (1) to substantiate the structure of natural capital, taking into account the natural resource and ecosystem approaches; (2) to clarify the concepts of "function" and "services" in relation to abiotic and biotic components of the environment; (3) to generalize and analyze the classifications of ecosystem services, and to develop the authors' classification; (4) to identify the most common methods for the economic assessment of natural capital components, and to implement these methods within a specific territory.

\section{Materials and Methods}

This article is devoted to the development of a consistent approach to natural capital, which serves as the basis for clarifying the methodical tools/guidelines for its economic assessment.

The research framework included four steps of analysis and assessment. In individual steps, various methods and materials were used, which are summarized below:

Step 1. The current concept of natural capital.

By applying a systemic and evolutionary approach based on at least seventy papers [1-76] to the task, the concept of natural capital was clarified (see Section 3.1). The essence of natural resources and natural capital has been defined in terms of the evolution of views on the use of the natural factor in economic relations. We prove that three approaches to the construction of the structure of natural capital based on the resource and ecosystem approaches have been identified. The authors' structure of natural capital is proposed, taking into account the fundamental principles of its formation.

Step 2. Functions and ecosystem services: entity and classifications.

Regarding the evolution of ecosystem services theory (see Section 3.2) [52-69], the difference between functions and services is proved based on the analysis of domestic and foreign classifications; the authors' approach to its construction is recommended. The nature of the functions that distinguish the abiotic and biotic components of natural capital is revealed.

Step 3. Methods of economic assessment of natural capital (see Section 3.3).

By applying methods of economic statistics, the list of the most frequently encountered methods of economic assessment that are interlinked with the objects being evaluated is established (types of natural resources and ecosystem services) [16-76]. 
Step 4. Economic assessment of the natural capital of the Berezovsky region of the Khanty-Mansiysk Autonomous Area.

Through testing of methodological approaches to the economic assessment of the natural capital of the Berezovsky District of Khanty-Mansi Autonomous Okrug, the valuation of natural capital was performed (see Section 3.4) [19]. The territory was chosen because of three reasons: (1) the ecosystems of the north are extremely vulnerable; thus, (2) these ecosystems need more time to recover; (3) we were conducting special research for this territory in 2019 and obtained all the required data for the assessment of ecosystem services. Moreover, the Khanty-Mansi Autonomous Okrug is rich in mineral, oil, and gas resources, as well as in nature untouched by human activities. Hence, the most typical ecosystems of the region and their inherent ecosystem services were identified. The results of the assessment are presented for forest ecosystems, mountain ecosystems, and ecosystems of swamps, lakes, and rivers. The priority of the value of indirect use of ecosystem services over the value of direct use is established, as well as the higher value of biotic components compared to abiotic ones.

The research hypothesis was that the development of a consistent natural capital approach could contribute to the move towards sustainable development and to the achievement of the Sustainable Development Goals by 2030. The development of a consistent natural capital approach was made by (1) identifying three approaches to substantiating the structural components of natural capital, represented by abiotic and biotic components of ecosystems and their participation in the formation of the flow of "goods" and ecosystem services; (2) developing the authors' classification, including a list of supporting, provisioning, regulating, and social ecosystem services, taking into account the generalization of the existing studies on the topic; and (3) the establishment of the most common methods used for the economic assessment of natural resources and ecosystem services and testing them on a specific area.

The research was based on the systemic, evolutionary, and ecosystem approaches. A variety of scientific research and databases, relating to ecosystem valuation, formed the information base of this paper. The authors' observation period is from the middle of 20th century to the present.

\section{Results and Discussion}

\subsection{The Current Concept of Natural Capital}

The concept of natural resources has been used in social relations for a long time, and it initially characterized only the natural aspect.

In a Russian case study, Yu. N. Kurazhkovsky introduced a new term, environmental management, into scientific use in the late 50s of the twentieth century. In 1964, D.L. Armand published his book For Us and Grandchildren, where he formulated the principles of environmental management that anticipated the concept of sustainable development. Moreover, K.K. Markov, who headed the Faculty of Geography of Moscow State University from 1945 to 1955, was one of the first who realized the need to create a new scientific direction-training personnel for environmental management by integrating physical and economic geography within the framework of geographical science [39]. This indicated a gradual shift in the concept of natural resources from purely natural categories to categories of socioeconomic relations. D.L. Armand calls resources as "natural bodies and types of energy used by man, involved in economic relations" [40] (p. 6). The role of natural resources cannot be overestimated in the material life of society. All that a person uses is made of them (natural resources); without them, a person will not exist for several days. With minor changes, this definition of natural resources was included in the textbooks of nature management and environmental economics. For instance, "natural resources are elements of nature. Natural resources are the part of the overall natural conditions and the most important components of the environment. Natural resources are used to meet the diverse needs of society and production" [41] (p. 69). Another definition is that, "natural resources are bodies and forces of nature (various types of substances and energies) that are used or can be used to satisfy the needs of human society" [42] (p. 261). The legislative definition of 
natural resources given in the Russian Federal Law On Environmental Protection. It means that natural resources are components of the environment, natural objects and natural and anthropogenic objects that are used or can be used for economic or other activities as sources of energy, products food and commodities. Natural resources have a consumer value. It should be noted that this legislative act is practically the only one that defines the concept of natural resources.

In accordance with the classification criterion, which characterizes the main components of the environment, the following are distinguished: minerals (mineral resources), water resources, land resources, biological (plant and animal) resources, climate resources, air resources, energy resources of natural processes, integral resources (for example, recreational). In this case, the resources that constitute the consumer products (wild animals, medicinal plants, berries, mushrooms, etc.) are usually included in the number of natural resources. The raw material function assigned to natural resources by the industrial society is currently being supplemented by functions related to environmental, cultural, and spiritual components. In the late twentieth century, it led to the emergence of a new economic category called natural capital.

The term natural capital has been presented in the economic literature for a long time. It has been used to denote the totality of natural resources, replacing the term natural resource potential. Its extension occurred with the appearance of H. Daly and R. Costanza's work, called Natural capital and sustainable development [43,44], where natural capital (NC) gained the definition of "natural environment assets/stock that gives the flow of valuable goods and services in the future" [43]. So, natural capital has come to be seen as a stock that provides a flow of services over time. Sustainable flow, presented by the natural capital, has been defined as a natural income. According to the glossary, attached to the international project's report, called Economics of ecosystems and biodiversity (2010) [66] "Natural capital is an economic model of the limited physical and biological resources' stock, found on Earth, and an economic model of the limited ability of ecosystems to present its services" [66]. Other research shows natural capital as "an Earth's natural assets that provide availability of natural resources and ecosystem services for economic output and human well-being" [44] (p.14).

In the article [45], natural capital is considered as "the monetary terms of natural resources' stock and the total value of the ecosystem services" [45] (p. 12). It is also emphasized that the term capital implies obligatory value assessment. Recent research on the estimation and accounting of natural capital shows the given interpretation [28,46], where "natural capital is a way to describe Earth's natural assets, including soil, air, water, and living things, existing as complex ecosystems, which provide a range of services to humans" [46] (p.3). Thus, the analysis of multiple definitions shows that, in general, natural capital is considered as a natural asset, used as a source of goods' flow (feedstock, means of labor, consumer products, etc.) and ecosystem services (climatic control, erosion prevention et al.). Clarifying the concept of natural capital, some scientists consider to take into account only the natural resources, which have the characteristics of economic assets (1-the ownership rights, and 2-the fact of the obtained benefits from its use). Polemicizing with these scientists, it should be noted that it is quite difficult to speak about the ownership rights to ecosystem services. However, the fact of the obtained benefits from the use of ecosystem services is presented in many papers. So, it allows to consider the ecosystem services as a part of natural capital.

H. Daly and R. Costanza suggested to divide natural capital into two types: non-renewable (passive), which supplies goods as minerals, and renewable natural capital. Renewable natural capital by using the solar energy can self-repair. This type of natural capital was defined as active. The renewable one is a supplier of ecosystem products (wood, berries, mushrooms, etc.), as well as of the flow of ecosystem services (recreation, prevention of soil-erosion, hydrosphere regulation et al.). The renewable natural capital is depleted during economic activities and requires a full restoration, whereas the non-renewable natural capital depletes a lot but slower, and in contrast with the renewable natural capital it cannot be restored. The concept of H. Daly and R. Costanza assumes a constant stable value of natural flow (natural income) and preservation of a non-decreasing amount of natural capital. Thus, the formula of natural capital (TNC) consists of the sum of renewable natural capital 
(RNC) and non-renewable natural capital (NNC). According to H. Daly and R. Costanza, to ensure compliance with the preservation condition of TNC it requires reinvestments of a portion of income obtained from NNC into the restoration of renewable natural capital [43]. On the one hand, abiotic components are considered as a part of natural capital in the works [47-52], where non-renewable exhaustible resources (minerals) and renewable inexhaustible resources-abiotic flows (solar, wind, hydro, and geothermal energy)—on the other hand, ecosystem capital (ecological structures and flows of ecosystem services, including receiving consumer products) (Figure 1).

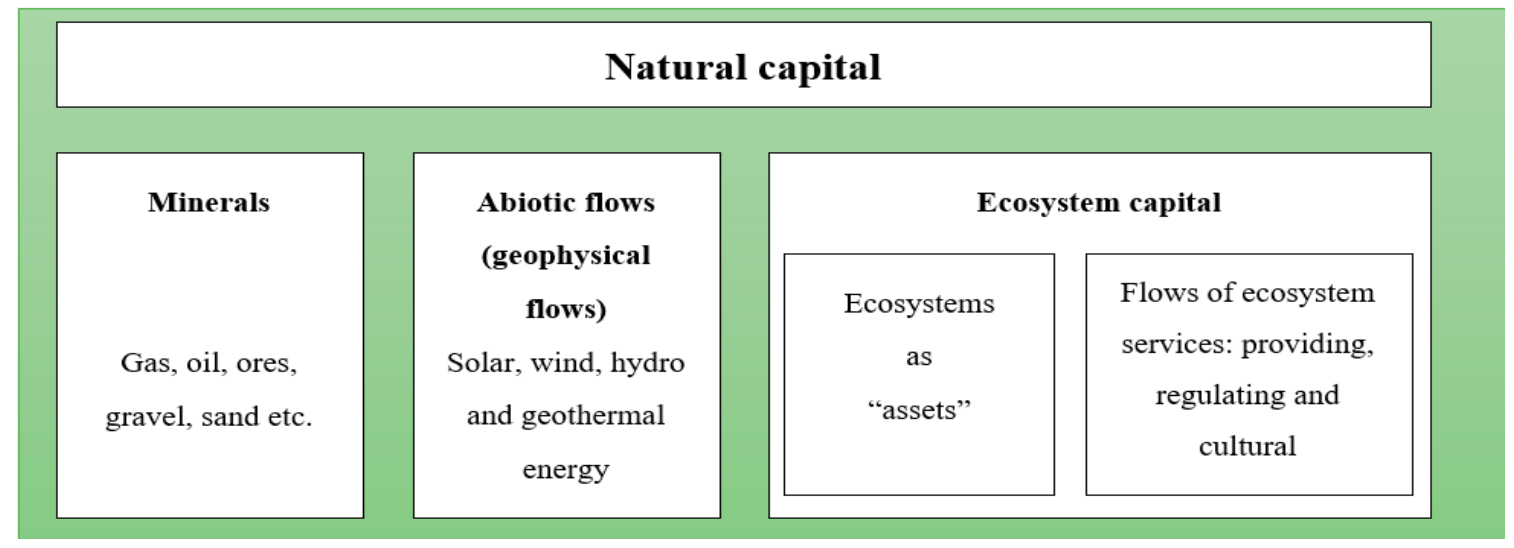

Figure 1. Main components of natural capital [52] based on ([53] with modifications).

The peculiarity of the given approach to the natural capital refers to the abiotic renewable components, where it is a matter of the flow of the services (to be more precise: the flow of the abiotic services). The unit ecosystems as assets means the stocks of renewable natural resources that supply a flow of ecosystem services.

The author [45] assumes a slightly different interpretation (Figure 2).
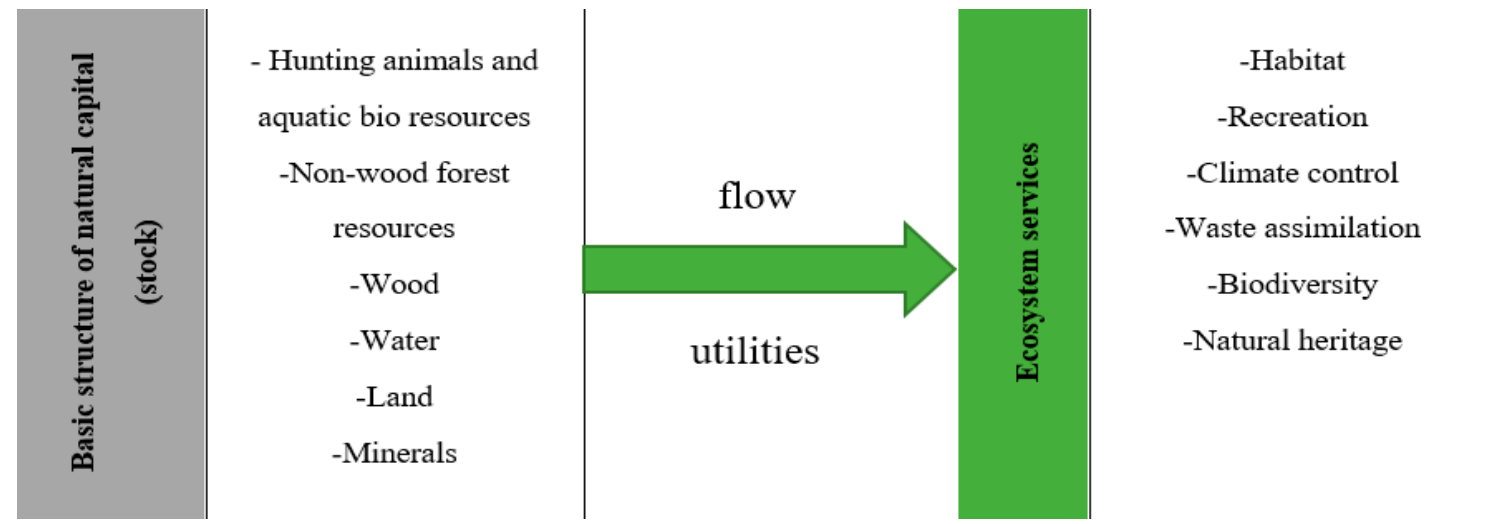

Figure 2. Conceptual structure of natural capital.

Figure 2 demonstrates the basic structure of natural capital, which combines all abiotic components (renewable and non-renewable components, including biotic, satisfying the need for consumer products). From the analysis of the formation of the structure of natural capital, it follows that there are three approaches:

- Ecosystem-based approach, in which all abiotic and biotic components combine within the ecosystem. These components supply ecosystem goods and services. The approach is to be known as a wider approach to the definition of term functions when all functions to be performed as ecosystem functions [54,55]. According to [56] these functions/services-are the "material, energy and information flows, arising from natural capital stocks ... " [56] (p. 9). According to this 
definition, the flow of natural resources is also an ecosystem service. The two of the followed-up approaches are defined as narrow whereby functions undertaken by biotic components called ecosystem functions.

- Resource approach, under which all abiotic components implement resources' functions. The result of resources' functions implementation is the supply of goods' flow. As far as the biotic components are concerned, these components perform the resource functions when supplying the consumer products (natural resources). Other functions of biotic components are being implemented into the flow of ecosystem services (ecosystem) [57].

- Mixed approach, where different combinations of abiotic and biotic components and their functions are possible.

From the authors' standpoint of the natural capital's structure, its construction is based on the system of proposed principles. These principles are shown in Figure 3. The basic principles include the following:

- Division into two types of natural capital is relative, because the abiotic components, as well as biotic ones, represent as equal parts of geosystems. In terms of sustainable flow (natural income), the most appropriate recommendations were demonstrated by H. Daly and R. Costanza;

- Biotic components, which form the ecosystem, realize only the ecosystem functions, supplying ecosystem services. The condition makes it possible to consider resource functions for the provision of consumer goods as provisioning ecosystem services;

- In order to avoid misinterpretation, the function focused on meeting the needs in goods of consumption and inherent in renewable abiotic components (water, atmosphere) considered as provisioning ecosystem services;

- Soil fertility (relatively renewable) is conditionally belonged to abiotic components that (1) supply the goods' flow in the form of humus required for growing agricultural crops and (2) simultaneously take part in human life and ecosystem functioning, performing ecosystem functions;

- Abiotic components, as well as biotic, perform resource and ecosystem functions. Implementing resource approach, the object of scientific research is goods' flow. As for ecosystem approach, the object is the flow of ecosystem services. It is shown in the structure of natural capital (Figure 3).

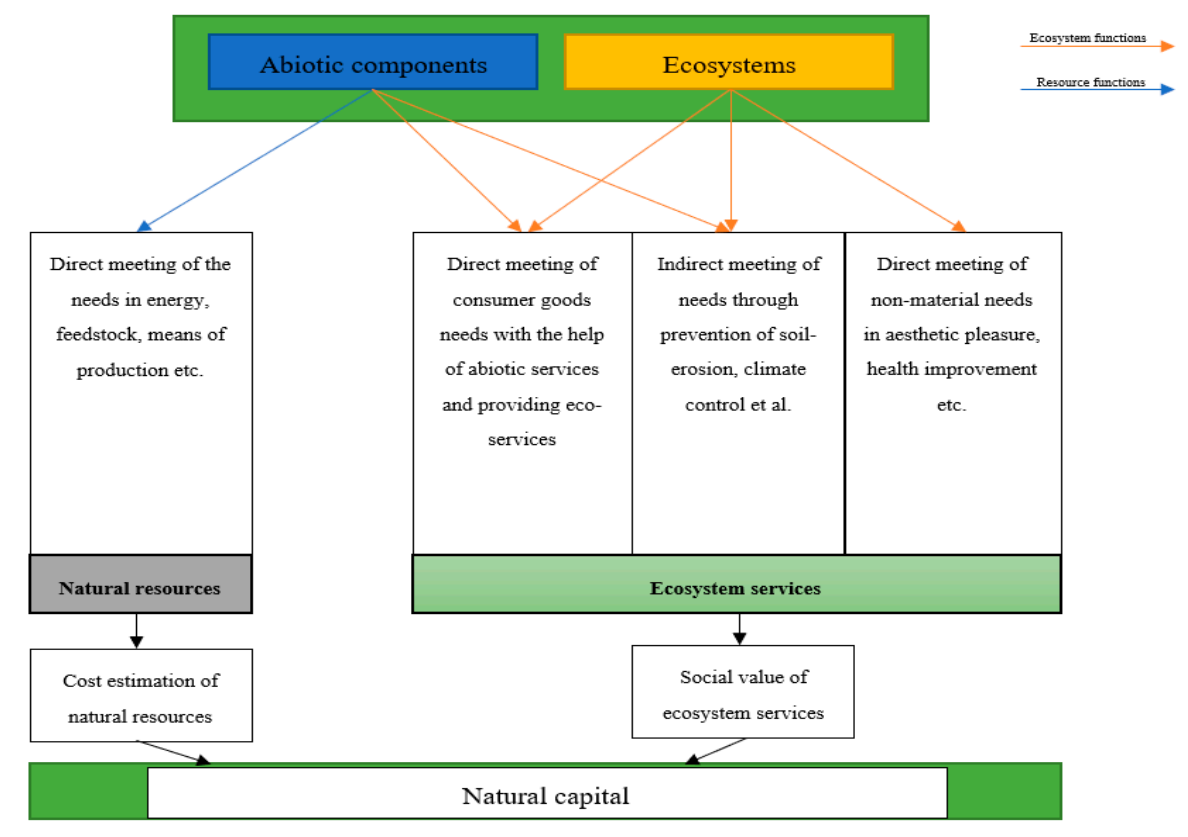

Figure 3. Structure of natural capital. 


\subsection{Functions and Ecosystem Services: Entity, Classifications}

According to the research [58], Carson R. (1962), Krutilla J.V., Fisher A.C. (1975), Ehrlich P.R., Ehrlich A.H. (1981) have been studying ecosystem functions and services since 1960s. Although there still exist no clear and universally accepted definitions. Some researchers perceive them as synonyms; others hold the view of service as functions that provide economic benefits; one more understanding when services are considered as a result of function's implementation (understanding of the term ecosystem services, with which the authors of this paper agree) $[59,60]$. In the dictionary of S.I. Ozhegov, function is defined as "work performed by an organ, an organism ... " or as "a duty, a range of activities (official functions) according to the work" [61] (p. 795); and a service is "an action that brings help, benefit to others" [61] (p. 776). Thus, the result of function's implementation is the formation of service (benefit, help to others). Their difference is also evidenced by the fact that a service can be the result of implementation of several functions and vice versa [52]. Clear division of biosphere functions is presented in A. A. Tishkov's research [62]. A.A. Tishkov consider the functions based on characteristics of biosphere processes. These processes include creation, transformation, destruction and accumulation of organic material on the surface, taking into account the relations between different kind of organisms' groups and its habitat. The result of ecosystems' functioning and realization of biosphere functions is a flow of material (products/goods) and non-material (services) values.

The term ecosystem services was introduced into scientific parlance in 1981, although the definition of social functions relating to forests was presented in publications of the 1970s, when the first recommendations of economic assessment appeared [63]. The problem of multi-purpose use of forests was discussed even earlier, during the V World Forest Congress [64]. As soon as the works of R. Costanza and H. Daly appeared (1992, 1977), ecosystem services began to consider as the components of natural capital that possess an economic estimation [43,54,55]. Classifications and types of ecosystem functions and services had been studied by many researchers, such as de Grott R.S. (1987, 1992), E.l. Serafy S. (1989, 1997); Dixon J.A., Sherman P.B. (1990), Daily G. (1997), et al. [55]. One of the first list of ecosystem services included 17 main goods and services, provided by the terrestrial ecosystem [54]. Largely, the list includes soil-formation, recreation, nitrogen cycle, water cycle and water supply, climate regulation of habitat, flood and storm protection, food and raw material, genetic resources, the balance of the atmospheric air, pollination and other services. In fact, the given list became the base for all subsequent research regarding the development of classifications. The next step was the emergence of generally accepted classification in the summary reports of (1) Millennium Ecosystem Assessment's project, (2) The Economics of Ecosystems and Biodiversity-TEEB's international project, (3) European Environment Agency (The Agency developed CICES (Common International Classification of Ecosystem Services)), and in (4) National Strategy for Biodiversity Conservation of Russia. All classifications contain three main categories of ecosystem services that benefit human and could be evaluated in the form of economic estimation:

- Provisioning (productive), these ecosystem services benefit people with material goods (food, livestock feed). The classification demonstrated in works $[65,66]$ additionally takes into consideration water for drinking and industrial needs, also, genetic resources that, in the Russian classification, are classified as other types of ecosystem services;

- Regulating (environment-forming), these ecosystem services maintain biosphere processes on Earth and make favorable conditions for human beings;

- Cultural (informational and spiritual-aesthetic or social), these ecosystem services benefit people with the satisfaction by non-material human needs for information, and cultural, spiritual, and scientific needs, also needs for education and health-improvement.

So far, as differences are concerned, the first relates to inclusion the supporting ecosystem services (nutrient cycling, photosynthesis, and soil formation) into the classification. The supporting ones admittedly shall not be monetary evaluated, but considered as a necessary condition for other ecosystem services' creation [65]. The second difference is linked to the accounting of such ecosystem service as "ensuring natural habitats for migrating species" [66], which is absent in the classification demonstrated 
in the research [67]. The third one is about the ambiguity over identification of certain types of ecosystem services (water, genetic resources). Moreover, the recreation is separated as a distinct group in Russian classification [48,52]. This Russian classification divides the ecosystem services into four types, such as production, environment-forming, informational and recreational.

The analysis of the ecosystem services' classifications allows to perform the following recommendations:

- To exclude the variety of definitions of the same ecosystem services types (productive, provisioning, providing, etc.) or (regulating, regulative, environmental, environment-forming, etc.) or (informative, informational, cultural, social etc.);

- To consider supporting ecosystem services as the fourth group of ecosystem services with the no monetary assessment;

- On account of the need to compare the value of the natural capital's components, it is necessary to ensure unambiguity in the content of the main groups of ecosystem services;

- To combine all types of ecosystem services that satisfy the non-material human needs (cultural, aesthetic, educational, recreational, etc.) into one group of social ecosystem services.

The proposed classification of ecosystem services, reflecting the authors' vision, is given in Figure 4. Four groups of ecosystem services are used in the classification: supporting, provisioning, regulating, and social. Supporting ecosystem services, as mentioned before, shall not be economically evaluated. The term provisioning is applied due to the fact that ecosystem services provide people with not only products but also with fuel, raw materials, etc. The definition of regulating more accurately reflects the nature of functions. Social ones reflect the satisfaction of non-material human needs that ensure the improvement of human potential. As far as the types of ecosystem services are concerned, water resources that meet the needs in drinking water, are considered as provisioning ecosystem service. We assume that the provisioning services include the services for provisioning of genetic resources for medical purposes, for the preservation of ornamental plants and animals, which characterize the direct meeting the needs.

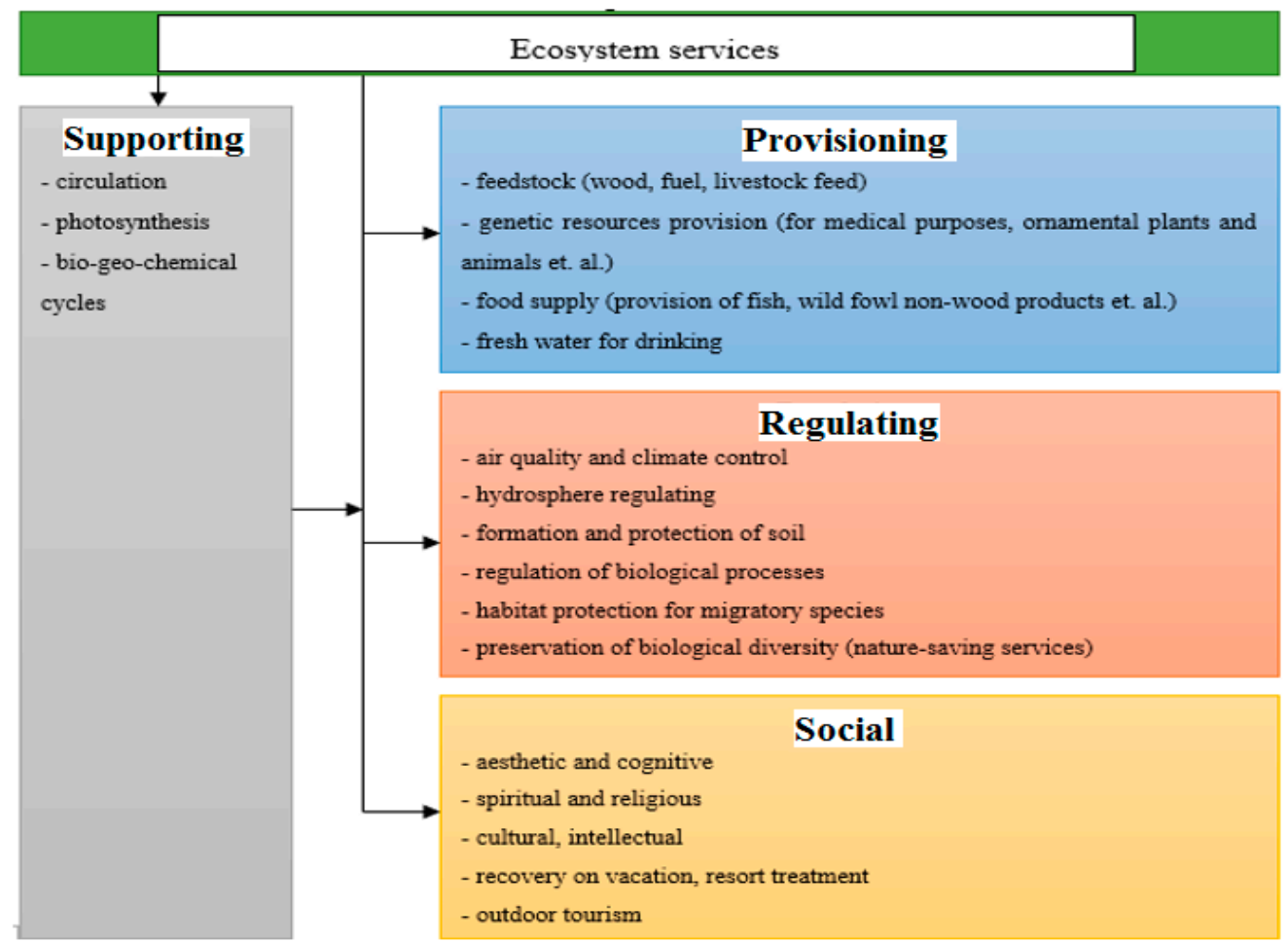

Figure 4. Classification of ecosystem services. 
It is offered to include the service habitat protection for migratory species (protection of the habitats) into the list of regulating ecosystem services. It helps to cultivate the generations of fauna under the conditions of Specially Protected Natural Reservations - SPNR. The next ecosystem service is also connected with the functioning of SPNA, it provides the preservation of biodiversity (the result of environmental-saving functions: reference, refugium, reserve and monumental)

We offer to combine all types of ecosystem services that satisfy the non-material human needs (including health-improvement needs) into one group of social ecosystem services; it has a broader concept than cultural.

Each component of the natural environment performs a specific set of functions. As for abiotic components (lithosphere, atmosphere, hydrosphere, soil), these components are called resources, because the result of its realization is meeting the material human needs in energy, raw materials, and means of production, i.e., natural resources are the case in point. The biotic components (an ecosystem) perform the ecosystem functions, supplying the flow of ecosystem services. As far as the functions provided by abiotic and biotic components (ecosystems) of natural capital are concerned, the model could be shown schematically, as follows (Figure 5).

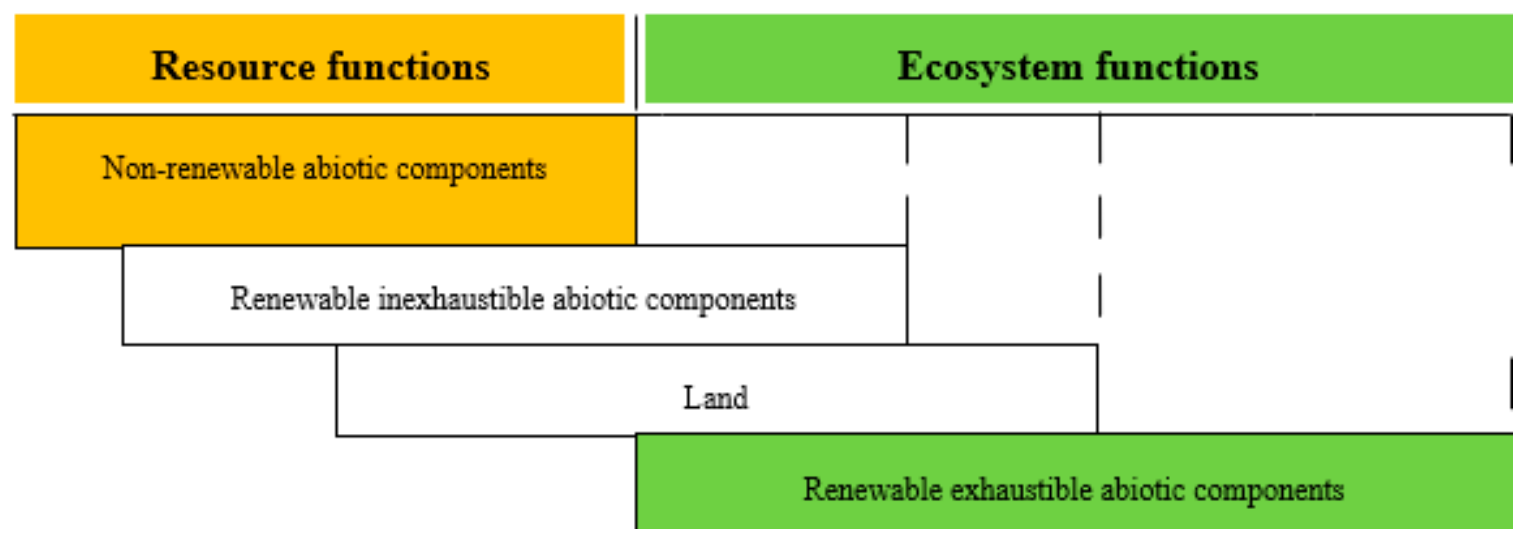

Figure 5. Abiotic and biotic components of natural capital and their functions.

Among abiotic components, the lithosphere performs only resource functions, although ecological functions of the lithosphere are considered in the work [68], e.g., those that ensure the life of biota due to the minerals of biophilic series. As a matter of fact, the given function is considered as supporting ecosystem service. In turn, atmosphere and hydrosphere implement both resource functions and ecosystem ones. Atmosphere and hydrosphere provide services as a form of freshwater and clean air. Biotic components form ecosystems and perform a number of ecosystem functions, supplying the flow of provisioning, regulating, and social ecosystem services. The soil holds a specific place. As a substrate, it contributes to the growth of agricultural plants, and it is considered as a natural resource from this perspective. At the same time, soil is a supplier of a number of ecosystem services [69].

\subsection{Methods of Economic Assessment of Natural Capital}

Due to the increased need for rational use of natural capital and for minimization of its depletion, the problem of economic assessment became up-to-dated. According to N.N. Lukyanchikov, the concern is in "the assessment of natural capital's value in monetary terms within the fixed socio-economic conditions of production and at a prescribed mode of environmental management and ecological limitations on economic or any other activities" [70].

Economic assessment of natural resources triggers its inclusion into economic relations. So, it allows to take into account previously free natural resources and ecosystem services in the process of making management decisions, while reducing degradation of the environment. The economic factor of motivation to preserve nature appears. The system of monetary estimation of natural capital and its components is supposed to solve a huge set of objectives: creating the most advanced system of national 
wealth accounting; improving the efficiency of the environmental management's state regulation; solving the problem of resource saving; developing the payment systems for the use of natural resources; determining the amount of economic damage caused by the violation of national wealth et al.

Currently, economic valuation, especially in relation to ecosystem services, remains controversial. A few researchers deny the economic assessment of natural capital, considering nature to be priceless. However, only accounting the natural capital in economic terms could help to solve the problem of preserving the health of ecosystems, to create the mechanisms that ensure a balance in the "society - nature" system. The most developed methods are the methods for economic assessment of natural resources (mineral resources, water, and soil ones, in terms of their performance of resource functions), as well as the methods for economic assessment of provisioning ecosystem services (wood, hunting resources, fish, etc.) [71-74]. A number of these methodical tools are officially approved; much research in recent years has employed the other part of tools.

The main difficulties are associated with the economic assessment of regulating and social ecosystem services. However, the examples of its implementation are becoming more and more numerous: the assessment of Berendeyevka Park [16], the assessment of biological resources of Moscow [24], the assessment of the Lyoser National Park [75] and natural system of the Kurshskaya Kosa [18], the assessment of ecosystem services of Earth's Wetlands [76], the assessment of natural capital of Tomsk region [45], the assessment of recreational service and a number of ecosystem services for forests and wetlands of Murmansk region, the assessment of environment-forming services of geosystems of Arkhangelsk region, Mezensky and Leshukovsky areas, the assessment of direct and indirect ecosystem services of geosystems of Vorkutinsky district (Komi Republic, Russia), the assessment of the natural capital of Nenets Autonomous region, et al. [77], the assessment of the St. Lucia protected area in South Africa [78], the assessment of the value of the protected area of national parks in Uganda [79], Mangrove ecosystems [80], the assessment of the value of biodiversity and ecosystem services of a coal-mining area in the Kemerovo region [44], etc.

The analysis demonstrates that the first method to be used in assessment procedure in the $60 \mathrm{~s}$ were costing method, based on the summation of labor costs for the development and maintenance of natural resources [81]. The following modifications of this method were substitution method, method of replacement cost, method of preventive costs, and method of prevented damage (Figure 6). In the first case, the substitution method presumes an assessment of costs of a service with equivalent utility under the use of any ways. In the second case (method of replacement cost), costs on a possibly full restoring of a copy of the evaluated service are defined. The method of preventive costs involves the assessment of costs, which are necessary to prevent possible damage caused by the actual absence of the evaluated service. The method of prevented damage is based on the assumption that the value of an assessed service is determined by the damage that generates when the service is lost (Figure 6). Along with the cost group of methods, income group of methods began to be used: market price method, rental method, income method, method of the alternative cost, method of income, and method of the production function based on the calculation of the expected income.

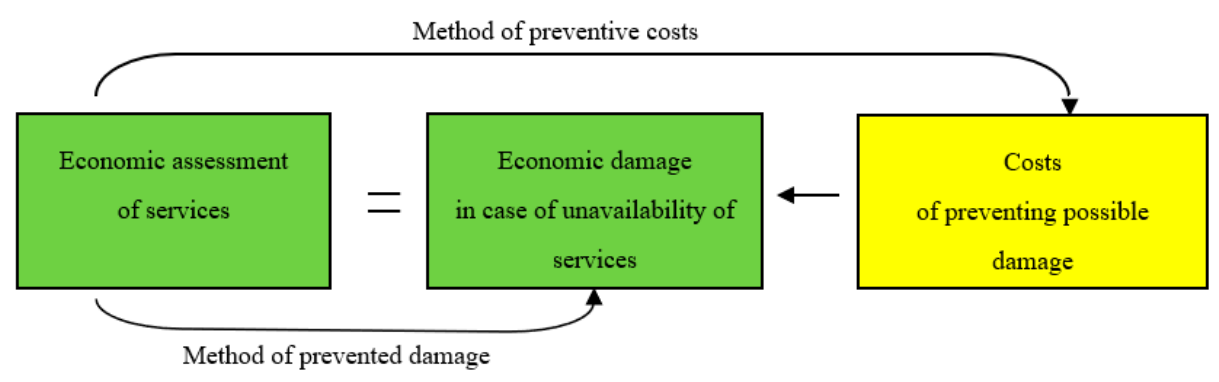

Figure 6. Cost group of methods for natural capital's assessment. 
Market price method allows to utilize prices for goods and services, used on the world and domestic markets, for the assessment. The income method is associated with the calculation of the profit that can be obtained by investing in the evaluated object. The rental method is often used, which is based on the assessment of profit (differential rent), formed due to the best natural characteristics and does not require labor costs, does not depend on technology. The actual rent is a part of the total profit and must be returned by the user of the resource to the owner of the resource in the form of tax or rent. The income group of methods also includes the method of the alternative costs, in the application of which the assessment is carried out on the basis of the profit that could have been obtained with an alternative use of the object being evaluated. The method of income is used for assessment of the service that increases the income of the consumed service. The method of the production function (assessment of the marginal product) is produced by the dynamic modelling method with the use of the production function; it allows to allocate changes in the economic result depending on the contribution of ecosystem services. The comparative group of methods are often used in economic assessment, when the value of a resource/service is established as a result of its comparison with similar resource/service that already have an assessment. This comparative group of methods includes analog method (method of transferring values). For the sake of simplicity, the analog method employs an already existing indicator of the value of a service or the average one of some several indicators. When using a meta-analysis (that allows to identify the dependence of changes in the value of ecosystem services on many characteristics of the territory), the introduction of correction coefficients is envisaged for the existing estimates of ecosystem services, which are considered as a standard. Recently, the method of substituted goods comes into sight. This method provides the replacement of the product, not having a market, with the product, which has the real market. It helps to establish an approximate assessment of a product or service depending on the degree of interchangeability.

A large group of methods is formed by the sociological group of methods, such as the method of subjective assessment (willingness to pay), transportation cost method, and method of hedonic pricing (assessment of pleasure or price preferences). These methods are gaining a wider acceptance, especially since the results can be quite reliable if the methods are conducted correctly. The method of subjective assessment involves the assessment of the willingness of people to pay for the alternative options of the possible development, or the assessment of their willingness to accept a compensation. The transportation cost method is used to evaluate services that require travel costs, which determine the value of the service. The method of hedonic pricing is focused on the obtainment of an environmental good's assessment at the prices of the real estate market (the willingness of people to pay for goods with the best environmental factors). The cost group of methods, the income group of methods, and the comparative group of methods are related to the economic assessment methods, in contrast to the last group - the sociological group of methods, which is related to the sociological assessment methods. All the social ecosystem services, including tourism and recreation, are usually estimated by employing sociological assessment methods. Table 1 proves this fact. Nowadays, this problem is on agenda, there is much research for the purpose of how to evaluate touristic aspects [82-85]. However, looking at the North territory such as the Khanty-Mansiysk Autonomous Area (the object of our assessment procedure), where the touristic aspect is poorly developed, it should be mentioned that this paper does not observe this aspect scrupulously. The analysis of the studies devoted to the economic assessment of the components of natural capital makes it possible to identify the most frequently used methods, which usually utilize during the assessment procedures (Table 1). Table 1 is based on much research, such as $[16,17,19,24,44,45,71-74,77]$. 
Table 1. The most frequently used methods.

\begin{tabular}{|c|c|c|c|c|c|c|c|c|c|c|c|}
\hline \multirow[b]{2}{*}{$\begin{array}{l}\text { Methods of } \\
\text { Assessment }\end{array}$} & \multicolumn{3}{|c|}{ Natural Resources } & \multicolumn{4}{|c|}{ Provisioning Ecosystem Services } & \multicolumn{4}{|c|}{ Regulating Ecosystem Services } \\
\hline & $\begin{array}{l}\text { Mineral } \\
\text { Resources }\end{array}$ & $\begin{array}{c}\text { Water } \\
\text { Resources } \\
\text { (Resource } \\
\text { Functions) }\end{array}$ & $\begin{array}{c}\text { Soils, } \\
\text { (Resource } \\
\text { Functions) }\end{array}$ & $\begin{array}{c}\text { Water } \\
\text { Resources } \\
\text { (Surface } \\
\text { Drinking } \\
\text { Water) }\end{array}$ & $\begin{array}{c}\text { Provision } \\
\text { of Fish } \\
\text { and Fowl }\end{array}$ & $\begin{array}{c}\text { Provision } \\
\text { of Wood, } \\
\text { Feed for } \\
\text { Livestock }\end{array}$ & $\begin{array}{c}\text { provision of } \\
\text { Genetic } \\
\text { Resources, } \\
\text { Non-Wood } \\
\text { Resources }\end{array}$ & $\begin{array}{c}\mathrm{CO} 2 \\
\text { Deposition }\end{array}$ & $\begin{array}{c}\text { Reducing } \\
\text { Pollution of } \\
\text { the } \\
\text { Atmosphere }\end{array}$ & $\begin{array}{l}\text { Erosion } \\
\text { Control }\end{array}$ & $\begin{array}{l}\text { Oxygen- } \\
\text { Producing }\end{array}$ \\
\hline $\begin{array}{l}\text { Substitution } \\
\text { method }\end{array}$ & & & & & & & & & + & + & + \\
\hline $\begin{array}{l}\text { Method of } \\
\text { replacement cost } \\
\text { Method of } \\
\text { preventive costs }\end{array}$ & & & & & + & + & & & & & \\
\hline $\begin{array}{c}\text { Method of } \\
\text { prevented damage }\end{array}$ & & & & & + & & & & & & \\
\hline Rental method & + & + & + & + & + & + & & & & & \\
\hline Income method & + & + & + & + & + & + & + & & & & \\
\hline $\begin{array}{c}\text { Market price } \\
\text { method }\end{array}$ & & & + & & & & & + & & & \\
\hline $\begin{array}{l}\text { Method of income } \\
\text { Analog method }\end{array}$ & & & & & & & & & & + & \\
\hline $\begin{array}{c}\text { (method of } \\
\text { transferring } \\
\text { values) }\end{array}$ & & & & & & & & & + & + & \\
\hline $\begin{array}{c}\text { Method of } \\
\text { substituted goods }\end{array}$ & & & & & & & & & & & \\
\hline $\begin{array}{l}\text { Method of the } \\
\text { production } \\
\text { function }\end{array}$ & & & & & & & & & & & \\
\hline $\begin{array}{l}\text { Method of the } \\
\text { alternative cost }\end{array}$ & & & & & & & & & & & \\
\hline $\begin{array}{l}\text { Method of } \\
\text { subjective } \\
\text { assessment }\end{array}$ & & & & & & & & & & & \\
\hline Transportation & & & & & & & & & & & \\
\hline cost method & & & & & & & & & & & \\
\hline Method of & & & & & & & & & & & \\
\hline hedonic pricing & & & & & & & & & & & \\
\hline
\end{tabular}


Table 1. Cont.

\begin{tabular}{|c|c|c|c|c|c|c|c|c|c|c|c|c|c|}
\hline \multirow[b]{2}{*}{$\begin{array}{l}\text { Methods of } \\
\text { Assessment }\end{array}$} & \multicolumn{6}{|c|}{ Regulating Ecosystem Services } & \multicolumn{7}{|c|}{ Social Ecosystem Services } \\
\hline & $\begin{array}{l}\text { River } \\
\text { Flow } \\
\text { Regulation }\end{array}$ & $\begin{array}{l}\text { Weakening } \\
\text { of Natural } \\
\text { Disasters }\end{array}$ & $\begin{array}{l}\text { Accumulation } \\
\text { of Pollution } \\
\text { by Swamps }\end{array}$ & $\begin{array}{l}\text { Ensuring } \\
\text { Water } \\
\text { Quality of } \\
\text { Terrestrial } \\
\text { Ecosystems }\end{array}$ & $\begin{array}{c}\text { Habitat } \\
\text { Protection } \\
\text { for } \\
\text { Migrating } \\
\text { Biological } \\
\text { Species }\end{array}$ & $\begin{array}{l}\text { Preservation } \\
\text { of } \\
\text { Biodiversity }\end{array}$ & $\begin{array}{l}\text { Aesthetic } \\
\text { and } \\
\text { Cognitive } \\
\text { Value }\end{array}$ & $\begin{array}{l}\text { Wellness } \\
\text { Value }\end{array}$ & $\begin{array}{c}\text { Ethno- } \\
\text { Cultural } \\
\text { (Physical } \\
\text { Survival- } \\
\text { Private } \\
\text { Evaluation) }\end{array}$ & $\begin{array}{l}\text { Tourism } \\
\text { and } \\
\text { Recreation }\end{array}$ & $\begin{array}{l}\text { Informational } \\
\text { Value }\end{array}$ & $\begin{array}{c}\text { Spiritual } \\
\text { and } \\
\text { Religious } \\
\text { Value }\end{array}$ & $\begin{array}{l}\text { Cultural } \\
\text { Intellectual } \\
\text { Value }\end{array}$ \\
\hline $\begin{array}{l}\text { Substitution } \\
\text { method }\end{array}$ & & & & + & & & & & & & & & \\
\hline $\begin{array}{l}\text { Method of } \\
\text { replacement cost }\end{array}$ & & & & & + & & & & & & & & \\
\hline $\begin{array}{l}\text { Method of } \\
\text { preventive costs }\end{array}$ & & & + & & & & & & & & & & \\
\hline $\begin{array}{l}\text { Method of } \\
\text { prevented damage } \\
\text { Rental method }\end{array}$ & & + & & & & + & & & & & & & \\
\hline $\begin{array}{l}\text { Income method } \\
\text { Market price } \\
\text { method }\end{array}$ & + & & & & & & & + & + & & & & \\
\hline $\begin{array}{l}\text { Method of income } \\
\text { Analog method } \\
\text { (method of } \\
\text { transferring } \\
\text { values) }\end{array}$ & + & + & + & + & + & + & & + & & & & & \\
\hline $\begin{array}{l}\text { Method of } \\
\text { substituted goods } \\
\text { Method of the } \\
\text { production } \\
\text { function }\end{array}$ & & & & & & & & & & & & & \\
\hline $\begin{array}{l}\text { Method of the } \\
\text { alternative cost } \\
\text { Method of } \\
\text { subjective } \\
\text { assessment }\end{array}$ & & & & & & & + & & & + & & & \\
\hline $\begin{array}{l}\text { Method of } \\
\text { transport expenses } \\
\text { Hedonistic pricing } \\
\text { method }\end{array}$ & & & & & & & & & & + & & & \\
\hline
\end{tabular}


3.4. Economic Assessment of the Natural Capital of Berezovsky Region of the Khanty-Mansiysk Autonomous Area (Russia)

The results of economic assessment of the natural capital of Berezovsky region of the Khanty-Mansiysk Autonomous Area are presented as an example. However, the territory was chosen because of three reasons: (1) the ecosystems of the north are extremely vulnerable; thus, (2) these ecosystems need more time to recover; (3) we were conducting special research for this territory in 2019 and obtained all the required data for the assessment of ecosystem services. A broad approach to the natural capital concept is used in the assessment procedure, i.e., all goods/products and services are considered as ecosystem services. All estimates are given in annual measurement as of the end of 2019, according to the rate: $\$ 1$ USD is equal to "64.25" RUB. The study [19] has been used as a methodical basis for the economic assessment of ecosystem services. The assessment of natural capital are presented for forest ecosystems, mountain ecosystems, and ecosystems of swamps, lakes, and rivers (Tables 2-5).

According to the expert survey, a list of the most important ecosystem services has been identified (Table 3).

Evaluation of ecosystem services for land resources involves taking into account the soil texture (its mechanical composition), which is demonstrated in Table 4.

The value of direct and indirect use of ecosystem services is presented in Table 5.

Table 2. Ecosystems and landscapes of the Berezovsky region of Khanty-Mansi Autonomous Okrug (KhMAD).

\begin{tabular}{ccc}
\hline Ecosystems & Landscapes & Areas, $\mathbf{~ k m}^{\mathbf{2}}$ \\
\hline Forests of the temperate climatic zone (boreal area) & $2.1 . ; 2.2 . ; 5.2$. & $45,664.49$ \\
Mountains & $3 ; 5.3$ & $16,176.21$ \\
Swamps, lakes, and rivers & $1.1 ; 1.2 ; 4,5.1$ & $22,627.57$ \\
\multicolumn{2}{c}{ In total 84,468.27 } & \\
\hline
\end{tabular}

Note: landscape numbers reflect their location on the landscape map

Table 3. Ecosystem services.

\begin{tabular}{|c|c|c|c|c|c|c|}
\hline \multicolumn{2}{|c|}{ Ecosystem Services } & \multicolumn{3}{|c|}{ Abiotic Components } & \multicolumn{2}{|c|}{$\begin{array}{c}\text { Biotic } \\
\text { Components }\end{array}$} \\
\hline & & $\begin{array}{l}\text { Minerals } \\
\text { (MR) }\end{array}$ & $\begin{array}{l}\text { Land (soil) } \\
\text { (LR) }\end{array}$ & $\begin{array}{l}\text { Hydro sphere } \\
\text { (WR) }\end{array}$ & $\begin{array}{l}\text { Flora } \\
\text { (FL) }\end{array}$ & $\begin{array}{c}\text { Fauna } \\
\text { (FA) }\end{array}$ \\
\hline \multirow{5}{*}{ Provisioning } & Food & & + & & + & + \\
\hline & Fresh water & & & + & & \\
\hline & Fiber & & & & + & + \\
\hline & Biofuels & & & & + & \\
\hline & Raw materials & + & & & & \\
\hline \multirow{4}{*}{ Regulating } & $\begin{array}{l}\text { Climate and air } \\
\text { quality regulation }\end{array}$ & & + & + & + & + \\
\hline & Water regulation & & + & & + & \\
\hline & $\begin{array}{l}\text { Regulation of } \\
\text { soil-erosion }\end{array}$ & & & & + & \\
\hline & $\begin{array}{l}\text { Water and wastewater } \\
\text { treatment }\end{array}$ & & + & & + & \\
\hline
\end{tabular}


Table 4. Initial data on soils.

\begin{tabular}{cccc}
\hline Ecosystems & Landscapes & Areas, $\mathbf{k m}^{\mathbf{2}}$ & $\begin{array}{c}\text { Mechanical } \\
\text { Composition of Soils }\end{array}$ \\
\hline \multirow{3}{*}{ Forests of temperate climate zone } & 2.1 & $28,289.40$ & loam \\
& 2.2 & $16,133.80$ & loam \\
Mountains & 5.2 & 1241.29 & loam \\
\hline \multirow{2}{*}{ Swamps, lakes and rivers } & 3 & 1466.00 & crushed stone \\
& 5.3 & $14,710.21$ & crushed stone \\
\hline & 1.1 & 3503.00 & sandy loam-sand \\
& 1.2 & $16,360.20$ & sandy loam \\
& 4 & 144.60 & sandy loam \\
\hline
\end{tabular}

Table 5. The value of direct and indirect use of ecosystem services.

\begin{tabular}{|c|c|c|c|c|}
\hline \multirow[b]{2}{*}{ Ecosystems } & \multirow[b]{2}{*}{ Natural Resource } & \multirow{2}{*}{$\begin{array}{l}\text { Value of Direct } \\
\text { Use, thousand US } \\
\text { Dollars }\end{array}$} & \multicolumn{2}{|c|}{$\begin{array}{l}\text { Value of Indirect Use, } \\
\text { thousand US Dollars }\end{array}$} \\
\hline & & & $\begin{array}{l}\text { Ecological } \\
\text { Value of }\end{array}$ & $\begin{array}{l}\text { Socio-Cultura } \\
\text { Value of } \\
\text { Eco-Services }\end{array}$ \\
\hline \multirow{5}{*}{$\begin{array}{l}\text { Forests of the } \\
\text { temperate climate } \\
\text { zone }\end{array}$} & MR & $175,002.66$ & & \\
\hline & LR & 0.10 & $21,596.33$ & \\
\hline & WR & 4318.46 & 1800.01 & \\
\hline & FL and FA & 505.57 & $559,925.27$ & \\
\hline & $\begin{array}{l}\text { ecosystems in } \\
\text { aggregate }\end{array}$ & & & 247.91 \\
\hline \multicolumn{2}{|c|}{ Total for the Forest Ecosystem } & $179,826.79$ & $583,321.61$ & 247.91 \\
\hline \multirow{5}{*}{ Mountains } & MR & - & & \\
\hline & LR & - & 532.08 & \\
\hline & WR & 132.26 & 39.99 & \\
\hline & FL and FA & 373.25 & $82,253.55$ & \\
\hline & $\begin{array}{l}\text { ecosystems in } \\
\text { aggregate }\end{array}$ & & & 2945.20 \\
\hline \multicolumn{2}{|c|}{ Total for the Mountains Ecosystem } & 505.51 & $82,825.62$ & 2945.20 \\
\hline \multirow{5}{*}{$\begin{array}{l}\text { Swamps, lakes, } \\
\text { rivers }\end{array}$} & MR & & & \\
\hline & LR & 0.42 & $138,731.82$ & \\
\hline & WR & 7078.21 & 3050.19 & \\
\hline & FL and FA & 8805.11 & $142,151.05$ & \\
\hline & $\begin{array}{l}\text { ecosystems in } \\
\text { aggregate }\end{array}$ & & & 639.10 \\
\hline \multicolumn{2}{|c|}{$\begin{array}{c}\text { Total for the Swamps, Lakes, Rivers } \\
\text { Ecosystem }\end{array}$} & $15,883.74$ & $283,933.06$ & 639.10 \\
\hline \multicolumn{2}{|c|}{ In Total } & $196,216.04$ & $950,080.29$ & 3832.21 \\
\hline
\end{tabular}

Note: the assessment of socio-cultural values involves the sum of evaluated ecosystem services, such as tourism and recreation, as well as the aesthetic and cognitive value, mentioned in Table 1.

Table 5 shows that the value of direct use is five times lower than the value of indirect use. Forest ecosystems account for about $66.4 \%$ of the total value, $26.1 \%$ - ecosystems of swamps, rivers, and lakes, and about $7.5 \%$ for mountain ecosystems. Biotic components are the most valuable, with land resources in the second place, minerals on third, and the last are water resources. The obtained results of the rating should be taken into consideration when developing strategies for environmental management at all levels of regulation: federal, subjects of the federation, and municipal. 


\section{Conclusions}

Thus, the paper develops the consistent approach of natural capital by (1) identifying three approaches to substantiating the structural components of natural capital, represented by abiotic and biotic components of ecosystems and their participation in the formation of the flow of goods and ecosystem services; (2) developing the authors' classification, including a list of supporting, provisioning, regulating, and social ecosystem services, taking into account the generalization of the existing studies on the topic; and (3) the establishment of the most common methods used for the economic assessment of natural resources and ecosystem services and testing them on a specific area.

The list of conclusions are:

1. The evolution of views is identified on the use of natural factors in economic relations; the transition from natural resources to natural capital, as well as three approaches to the formation of the structure of natural capital are selected; the paper offers a system of principles, based on which the authors' structure of natural capital is constructed.

According to the analysis of the formation of the structure of natural capital, it follows that there are three approaches: (1) ecosystem-based approach, in which all abiotic and biotic components combine within the ecosystem. These components supply ecosystem goods and services. The approach is to be known as a wider approach to the definition of term functions when all functions to be performed as ecosystem functions; (2) resource approach, under which all abiotic components implement resources' functions. The result of resources' functions implementation is the supply of goods' flow. As far as the biotic components are concerned, these components perform the resource functions when supplying the consumer products (natural resources). Other functions of biotic components are being implemented into the flow of ecosystem services (ecosystem); (3) mixed approach, where different combinations of abiotic and biotic components and their functions are possible. From the authors' standpoint of the natural capital's structure, its construction is based on the system of proposed principles. The basic principles include the following:

- Division into two types of natural capital is relative, because the abiotic components, as well as biotic ones, represent as equal parts of geosystems. In terms of sustainable flow (natural income), the most appropriate recommendations were demonstrated by H. Daly and R. Costanza;

- Biotic components, which form the ecosystem, realize only the ecosystem functions, supplying ecosystem services. The condition makes it possible to consider resource functions for the provision of consumer goods as provisioning ecosystem services;

- In order to avoid misinterpretation, the function focused on meeting the needs in goods of consumption and inherent in renewable abiotic components (water, atmosphere) considered as provisioning ecosystem services;

- Soil fertility (relatively renewable) is conditionally belonged to abiotic components that (1) supply the goods' flow in the form of humus required for growing agricultural crops, and (2) simultaneously take part in human life and ecosystem functioning, performing ecosystem functions;

- Abiotic components, as well as biotic, perform resource and ecosystem functions. Implementing resource approach, the object of scientific research is goods' flow. As for ecosystem approach, the object is the flow of ecosystem services. It is shown in the structure of natural capital (Figure 3).

2. The difference between functions and services is proved; the nature of functions of the abiotic and biotic components of the natural capital is determined; and the list of ecosystem services, demonstrated in the authors' classification, is revealed too.

So, functions are based on the characteristics of biosphere processes. These processes include creation, transformation, destruction, and accumulation of organic material on the surface, considering the relations between different kinds of organism groups and its habitats. The result of ecosystems' functioning and realization of biosphere functions is a flow of material (products/goods) and non-material (services) values. 
The analysis of the ecosystem services classifications allows to perform the following recommendations:

- To exclude the variety of definitions of the same ecosystem services' type (productive, provisioning, providing, etc.) or (regulating, regulative, environmental, environment-forming, etc.) or (informative, informational, cultural, social, etc.);

- To consider supporting ecosystem services as the fourth group of ecosystem services with no monetary assessment;

- On account of the need to compare the value of the natural capital components, it is necessary to ensure unambiguity in the content of the main groups of ecosystem services;

- To combine all types of ecosystem services that satisfy the non-material human needs (cultural, aesthetic, educational, recreational, etc.) into one group of social ecosystem services.

As a result, four groups of ecosystem services are used in the authors' classification: supporting, provisioning, regulating and social. The list of ecosystem services is: (1) supporting: circulation photosynthesis, bio-geo-chemical cycles; (2) provisioning: feedstock (wood, fuel, livestock feed), genetic resources provision (for medical purposes, ornamental plants and animals, etc.), food supply (provision of fish, wild fowl non-wood products, etc.), fresh water for drinking; (3) regulating: air quality and climate control, hydrosphere regulating, formation and protection of soil, regulation of biological processes, habitat protection for migratory species, preservation of biological diversity (nature-saving services); (4) social: aesthetic and cognitive, spiritual and religious, cultural, intellectual, recovery on vacation, resort treatment, outdoor tourism.

3. The analysis of methods, used for the economic assessment of natural capital's components, shows the possibility of method application as an assessment tool for specific types of natural resources and ecosystem services.

Economic and sociological assessment methods are isolated. At the same time, the rental method, the income method, and the analogy method have the highest frequency of use in the context of all ecosystem service assessments.

4. The economic assessment of the natural capital of the Berezovsky district of Khanty-Mansi Autonomous Okrug has been carried by employing the broad approach to the natural capital concept. The evaluated natural capital of KhMAD shows a significant excess of the value of ecosystem services over the value of natural resources and the highest value of biotic components in comparison with abiotic ones.

According to the calculation, it shows that the value of ecosystem services is almost five times higher than the value of natural resources.

Author Contributions: All authors contributed to the development of the current paper. The concept of natural capital, the evolution of ecosystem theory, and method of economic assessment of natural capital were prepared by all authors (M.I., V.Y., and O.L), while V.Y. made an economic assessment of the natural capital of Berezovsky region of the Khanty-Mansiysk Autonomous Area. The detailed literature review in the introduction and laconic conclusion were done by both M.I. and V.Y. While M.I. examined the Russian vision, V.Y. researched the foreign experience. The revision (review and editing) of the proposed article were carried out by M.I., V.Y., and O.L. All authors have read and agreed to the published version of the manuscript.

Funding: The research was supported by the Ministry of Science and Higher Education in accordance with the state assignment for Ural State Mining University No. 0833-2020-0008, "Development and environmental and economic substantiation of the technology for reclamation of land disturbed by the mining and metallurgical complex based on reclamation materials and fertilizers of a new type". We obtained the scientific results with the staff of Center for the collective use by using the equipment of the Center for the collective use of scientific equipment of the Federal Scientific Center of biological systems and agricultural technologies of RAS (No Ross RU.0001.21 PF59, the Unified Russian Register of Centers for Collective Use-http://www.ckp-rf.ru/ckp/77384).

Acknowledgments: Polina Sergeevna Logvinenko and Alexander Nikolaevich Malyshev, 3rd-year student at the Ural State Mining University, took part in the translating process of the manuscript.

Conflicts of Interest: The authors declare no conflict of interest. 


\section{References}

1. Parker, J. 'Natural Capital': Ontology or Analogy? Debating Nat. Value 2018, 89-101. [CrossRef]

2. Maher, S.M.; Fenichel, E.P.; Schmitz, O.J.; Adamowicz, W.L. The economics of conservation debt: A natural capital approach to revealed valuation of ecological dynamics. Ecol. Appl. 2020, 30, e02132. [CrossRef] [PubMed]

3. Tilman, A.R.; Plotkin, J.B.; Akçay, E. Evolutionary games with environmental feedbacks. Nat. Commun. 2020, 11, 915. [CrossRef] [PubMed]

4. Canh, N.P.; Schinckus, C.; Thanh, S.D. The natural resources rents: Is economic complexity a solution for resource curse? Resour. Policy 2020, 69, 101800. [CrossRef]

5. Phillips, J. The sustainability dynamics framework-A holistic approach to define and evaluate sustainability and unsustainability in the anthropocene. Environ. Impact Assess. Rev. 2020, 84, 106436. [CrossRef]

6. Bordt, M. Discourses in ecosystem accounting: A survey of the expert community. Ecol. Econ. 2018, 144, 82-99. [CrossRef]

7. Polyanskaya, I.G.; Yurak, V.V. Balanced natural resource management of a region: Estimation by dynamic normal technique. Econ. Reg. 2018, 14, 851-869. [CrossRef]

8. Smol, M.; Marcinek, P.; Duda, J.; Szołdrowska, D. Importance of Sustainable Mineral Resource Management in Implementing the Circular Economy (CE) Model and the European Green Deal Strategy. Resources 2020, 9 , 55. [CrossRef]

9. Rajput, S.; Singh, S.P. Industry 4.0 model for circular economy and cleaner production. J. Clean. Prod. 2020, 277, 123853. [CrossRef]

10. Polyanskaya, I.G.; Yurak, V.V. Institutional assessment of environmentally oriented subsoil use. Econ. Reg. 2017, 13, 355-368. [CrossRef]

11. Polyanskaya, I.G.; Yurak, V.V.; Strovsky, V.E. Considering mining wastes as a factor of increasing the balance level of subsoil management in regions. Econ. Reg. 2019, 15, 1226-1240. [CrossRef]

12. Mantalovas, K.; Di Mino, G.; Del Barco Carrion, A.J.; Keijzer, E.; Kalman, B.; Parry, T.; Presti, D.L. European national road authorities and circular economy: An insight into their approaches. Sustainability 2020, 12, 7160. [CrossRef]

13. Luis, E.C.; Celma, D. Circular economy. A review and bibliometric analysis. Sustainability 2020, $12,6381$. [CrossRef]

14. Haas, W.; Krausmann, F.; Wiedenhofer, D.; Lauk, C.; Mayer, A. Spaceship earth's odyssey to a circular economy-A century long perspective. Resour. Conserv. Recycl. 2020, 163, 105076. [CrossRef]

15. Tishkov, A.A. Biosphere functions and ecosystem services of the Valdai National Park. Fed. State Inst. Natl. Park Valdai 2010, 1, 70-77.

16. Fomenko, G.A.; Fomenko, M.A.; Loshadkin, K.A.; Mikhailova, A.V. Monetary valuation of natural resources and ecosystem services in biodiversity conservation management: Experience of regional work. In Manual for Specialists_Practitioners; Research and Designing Institute "CADASTER": Yaroslavl, Russia, 2002; p. 80.

17. Bobylev, S.N.; Medvedeva, O.E.; Solovyova, S.V. Economics of Biodiversity Conservation; Institute of Environmental Economics: Moscow, Russia, 2002; p. 604.

18. Khodzhaev, R.S.; Vasilevich, I.Y. Synergetic Model of Economic Assessment of the Natural System (on the Example of the Curonian Spit National Park); Kaliningrad State Technical University: Kaliningrad, Russia, 2007; p. 177.

19. Yurak, V.V. Guidelines for the Economic Valuation of Regulatory and Social Ecosystem Services; Institute of Economics the Ural Branch of RAS: Yekaterinburg, Russia, 2018; p. 55. [CrossRef]

20. Westman, W.E. How much are nature's services worth. Science 1977, 197, 960-963. [CrossRef] [PubMed]

21. Pagiola, S.; von Ritter, K.; Bishop, J. How Much Does an Ecosystem Worth? The World Bank: Washington, DC, USA, 2004; p. 33.

22. De Groot, R.S.; Wilson, M.A.; Boumans, R.M.J. A typology for the classification, description and valuation of ecosystem functions, goods and services. Ecol. Econ. 2002, 41, 393-408. [CrossRef]

23. Braat, L.C.; de Groot, R. The ecosystem services agenda: Bridging the worlds of natural science and economics, conservation and development, and public and private policy. Ecosyst. Serv. 2012, 1, 4-15. [CrossRef]

24. Bobylev, S.N.; Sidorenko, V.N.; Stetsenko, A.V. Economic assessment of biological resources of the Moscow region. In Economic Analysis of Environmental Impact; VITA-Progress: Moscow, Russia, 2000; pp. 249-258. 
25. Tatarkin, A.I.; Polyanskaya, I.G.; Ignatyeva, M.N.; Yurak, V.V. Consistent assessment of the status and prospects of institutional and innovational subsurface resources management in the arctic zone. Econ. Reg. 2014, 3, 146-158. [CrossRef]

26. Hooper, E. Sustainable growth and financial markets in a natural resource-rich country. Struct. Chang. Econ. Dyn. 2019, 51, 341-348. [CrossRef]

27. Maes, M.J.A.; Jones, K.E.; Toledano, M.B.; Milligan, B. Accounting for natural capital has cross-cutting relevance for UK public sector decision-making. Ecosyst. Serv. 2020, 44, 101127. [CrossRef]

28. Hein, L.; Remme, R.P.; Schenau, S.; Bogaart, P.W.; Lof, M.E.; Horlings, E. Ecosystem accounting in the Netherlands. Ecosyst. Serv. 2020, 44, 101118. [CrossRef]

29. Experimental Biodiversity Accounting as a Component of the System of Environmental Economic Accounting Experimental Ecosystem Accounting (SEEA-EEA). Available online: https://www.unep-wcmc.org/system/dataset_file_fields/files/000/000/343/original/ANCA_Technical_ guidance_Experimental_Biodiversity_Accounting_final_.pdf?1450350840 (accessed on 21 September 2020).

30. Watson, S.C.L.; Preston, J.; Beaumont, N.J.; Watson, G.J. Assessing the natural capital value of water quality and climate regulation in temperate marine systems using a EUNIS biotope classification approach. Sci. Total Environ. 2020, 744, 140688. [CrossRef] [PubMed]

31. Cohen, F.; Hepburn, C.; Teytelboym, A. Is Natural Capital Really Substitutable? Annu. Rev. Environ. Resour. 2019, 44, 425-448. [CrossRef]

32. Bliss, S.; Egler, M. Ecological economics beyond markets. Ecol. Econ. 2020, 178, 106806. [CrossRef]

33. Pirgmaier, E. The value of value theory for ecological economics. Ecol. Econ. 2020, 179, 106790. [CrossRef]

34. Larue, L. The ecology of money: A critical assessment. Ecol. Econ. 2020, 178, 106823. [CrossRef]

35. Akbulut, B.; Adaman, F. The ecological economics of economic democracy. Ecol. Econ. 2020, 176, 106750. [CrossRef]

36. Ji, X.; Luo, Z. Opening the black box of economic processes: Ecological economics from its biophysical foundation to a sustainable economic institution. Anthr. Rev. 2020, 7, 231-247. [CrossRef]

37. Pan, Y.; Vira, B. Exploring natural capital using bibliometrics and social media data. Ecol. Soc. 2019, 24, 5. [CrossRef]

38. McKenna, T.; Blaney, R.; Brooker, R.W.; Ewing, D.A.; Pakeman, R.J.; Watkinson, P.; O’Brien, D. Scotland's natural capital asset index: Tracking nature's contribution to national wellbeing. Ecol. Indic. 2019, 107, 105645. [CrossRef]

39. Kapitsa, A.P.; Mukhin, G.D.; Zengina, T.Y. The history of the formation of the scientific school of rational environmental management at the Faculty of Geography of Moscow State University. In Rational Use of Natural Resources: Theory, Practice, Education, 8th ed.; Moscow State University: Moscow, Russia, 2012; p. 260.

40. Armand, D.L. For Grandchildren and Us; Publishing House Mysl: Moscow, Russia, 1966; p. 254.

41. Vorobiev, A.E.; Dyachenko, V.V.; Vilchinskaya, O.V.; Korchagina, A.V. Basics of Nature Management; Phoenix: Rostov-on-Don, Russia, 2004; p. 544.

42. Emelyanov, A.G. Basics of Nature Management; Publishing House ACADEMIA: Moscow, Russia, 2009 ; p. 304.

43. Costanza, R.; Daly, H.E. Natural capital and sustainable development. Conserv. Biol. 1992, 6, 37-46. [CrossRef]

44. Fomenko, G.A.; Fomenko, M.A.; Mikhailova, A.V.; Mikhailova, T.R. Economic Assessment of Specially Protected Natural Areas of Kamchatka: Practical Results and Their Importance for the Conservation of Biodiversity; Research and Designing Institute "CADASTER": Yaroslavl, Russia, 2010; p. 156.

45. Tsibulnikova, M.R. Accounting and Valuation of Natural Capital in Territorial Administration; Tomsk Polytechnic University: Tomsk, Russia, 2018; p. 163.

46. Science for Environment Policy. Taking Stock: Progress in Natural Capital Accounting. In-Depth Report 16 Produced for the European Commission, DG Environment by the Science Communication Unit, UWE, Bristol. 2017. Available online: http://ec.europa.eu/environment/integration/research/newsalert/pdf/natural_ capital_accounting_taking_stock_IR16_en.pdf (accessed on 21 September 2020).

47. Glazyrina, I.P. Natural Capital in an Economy in Transition; Autonomous Non-Profit Organization National Information Agency “Natural Resources": Moscow, Russia, 2001; p. 204.

48. Bobylev, S.N.; Bukvareva, E.N.; Grabovskiy, V.I.; Danilkin, A.A.; Dgebuadze, Y.Y.; Drozdov, A.V.; Zamolodchikov, D.G.; Kraev, G.N.; Tishkov, A.A.; Filenko, O.F.; et al. Ecosystem Services of Terrestrial Ecosystems in Russia: First Steps; Wildlife Conservation Center Moscow: Moscow, Russia, 2013; p. 45. 
49. Liu, S.; Costanza, R.; Troy, A.; D’Aagostino, J.; Mates, W. Valuing New Jersey's ecosystem services and natural capital: A spatially explicit benefit transfer approach. Environ. Manag. 2010, 45, 1271-1285. [CrossRef]

50. Weber, J.L. Ecosystem Natural Capital Accounts: A Quick Start Package; Secretariat of the Convention on Biological Diversity: Montreal, QC, Canada, 2014; p. 248.

51. Heal, G.M.; Daily, G.; Ehrlich, P.; Salzman, J.E.; Boggs, C.; Hellman, J.; Hughes, J.; Kremen, C.; Ricketts, T.; Martiny, A.C. Protecting Natural Capital Through Ecosystem Service Districts. Sanford Environ. Law J. 2001, 20, 333-364. [CrossRef]

52. Bobylev, S.N.; Bukvareva, E.N.; Grabovskiy, V.I.; Danilkin, A.A.; Dgebuadze, Y.Y.; Drozdov, A.V.; Zamolodchikov, D.G.; Kraev, G.N.; Perelet, R.A.; Smelyansky, I.E.; et al. Ecosystem Services of Russia. Vol. 1. Terrestrial Ecosystem Services; Wildlife Conservation Center Moscow: Moscow, Russia, 2016; p. 148.

53. Maes, J.; Teller, A.; Erhard, M. Mapping and Assessment of Ecosystems and thein Services. In An Analytical Framework for Ecosystem Assessments under Action 5 of the EU Biodiversity Stategy to 2020; Publiations office of the European Union: Luxemburg, 2013; p. 60.

54. Costanza, R.; D'Arge, R.; De Groot, R.; Farber, S.; Grasso, M.; Hannon, B.; Van Den Belt, M. The value of ecosystem services: Putting the issues in perspective. Ecol. Econ. 1998, 25, 67-72. [CrossRef]

55. Daily, G. (Ed.) Nature's Services: Societal Dependence on Natural Ecosystems; Island Press: Washington, DC, USA, 1997; p. 392.

56. Bobylev, S.N.; Zakharov, V.M. Ecosystem Services and Economics; Center for Sustainable Development: Moscow, Russia, 2009; p. 71.

57. Ignatieva, M.N. Formation of the natural potential of the territory. News Ural State Min. Univ. 2014, 4, 51-56.

58. Bukvareva, E.N.; Grunewald, K.; Bobylev, S.N.; Zamolodchikov, D.G.; Zimenko, A.V.; Bastian, O. The current state of knowledge of ecosystems and ecosystem services in russia: A status report. Ambio 2015, 44, 491-507. [CrossRef]

59. Krutilla, J.V.; Fisher, A.C. The Economics of Natural Environments: Studies in the Valuation of Commodity and Amenity Resources; Yohn Hopkins University Press: Baltimore, MD, USA, 1975; p. 292.

60. Ehrlich, P.R.; Ehrlich, A.H. Extinction: The Causes and Consequences of the Disappearance of Species; Random House: New York, NY, USA, 1981; p. 305.

61. Ozhegov, S.I. Dictionary of the Russian Language; State Publishing House of Foreign and National Dictionaries: Moscow, Russia, 1953; p. 848.

62. Tishkov, A.A. Biosphere functions and ecosystem services of landscapes of the steppe zone of Russia. Arid Ecosyst. 2010, 16, 5-15.

63. Paulukyavichyus, G.B. Experience of quantitative assessment of ecological functions of Lithuanian forests. Forestry 1977, 1, 3-8.

64. Sheingauz, A.S. Multipurpose forestry: Experience in developing a system of concepts. Geogr. Nat. Resour. 1984, 2, 11-19.

65. Board, M.A. Millennium Ecosystem Assessment (MA). In Ecosystems and Human Well-Being: Synthesis; Island Press: Washington, DC, USA, 2005.

66. Project TEEB-Economics of Ecosystems and Biodiversity. Prospects for the Participation of Russia and Other CIS Countries. Available online: http://www.biodiversity.ru/programs/international/teeb/briefing.html (accessed on 28 July 2020).

67. National Strategy for Biodiversity Conservation of Russia. Available online: http://biodata.ecoinfo.ru/def/ a25.html (accessed on 28 July 2020).

68. Trofimov, V.T.; Ziling, D.G. Environmental Geology; CJSC Geoinformmark: Moscow, Russia, 2002; p. 415.

69. Dobrovolsky, G.V.; Striganova, B.R.; Goncharuk, N.Y.; Dorofeeva, E.I.; Sedov, S.N.; Sokolova, T.A.; Tolpeshta, I.I.; Tarko, A.M.; Fokin, A.D.; Smolina, G.A.; et al. Regulatory Role of Soil in the Functioning of Taiga Ecosystems; SCIENCE: Moscow, Russia, 2002; p. 364.

70. Lukyanchikov, N.N. Economic and Organizational Mechanism for Managing the Environment and Natural Resources; Autonomous Non-Profit Organization National Information Agency “Natural Resources”: Moscow, Russia, 1998; p. 236.

71. Balashenko, V.V.; Ignatyeva, M.N.; Loginov, V.G. Natural resources potential of northern region: Consistent features of comprehensive assessment. Econ. Reg. 2015, 4, 84-94. [CrossRef] 
72. Tatarkin, A.I.; Balashenko, V.V.; Loginov, V.G.; Ignatyeva, M.N. Methodological tools for assessing the investment attractiveness of renewable resources in northern and arctic territories. Econ. Reg. 2016, 12, 627-637. [CrossRef]

73. Dushin, A.V. Theoretical and Methodological Foundations of the Reproduction of the Mineral Resource Base; Institute of Economics the Ural Branch of RAS: Yekaterinburg, Russia, 2013; p. 296.

74. Loginov, V.G. Socio-Economic Assessment of the Development of Natural Resource Areas of the North; Institute of Economics the Ural Branch of RAS: Yekaterinburg, Russia, 2007; p. 311.

75. Van Beukering, P.J.H.; Cesar, H.S.J.; Janssen, M.A. Economic valuation of the Leuser national park on sumatra, indonesia. Ecol. Econ. 2003, 44, 43-62. [CrossRef]

76. Schuyt, K.D.; Brander, L. The Economic Values of the World's Wetlands; World Wildlife Fund: Gland, Switzerland; Amsterdam, The Netherlands, 2004; p. 33.

77. Krasovskaya, T.M. Nature Management of the North of Russia; Editorial URSS: Moscow, Russia, 2008; p. 288.

78. Creemers, G.; Liebenberg, L.; Massyn, P. The Economic Contribution of Key Conservation Areas in South Africa; IUCN: Gland, Switzerland, 1995.

79. Howard, P.C.; Davenport, T.R.B.; Kigenyi, F.W.; Viskanic, P.; Baltzer, M.C.; Dickinson, C.J.; Lwanga, J.; Matthews, R.A.; Mupada, E. Protected area planning in the tropics: Uganda's national system of forest nature reserves. Conserv. Biol. 2000, 14, 858-875. [CrossRef]

80. Lacerda, L. (Ed.) Mangrove Ecosystems; Springer: Berlin/Heidelberg, Germany, 2002; p. 287. [CrossRef]

81. Strumilin, S.G. To the Assessment of the Gratuitous Benefits of Nature; Nauka: Moscow, Russia, 1963; pp. $110-114$.

82. Chan, C.-S.; Nozu, K.; Zhou, Q. Tourism Stakeholder Perspective for Disaster-Management Process and Resilience: The Case of the 2018 Hokkaido Eastern Iburi Earthquake in Japan. Sustainability 2020, 12, 7882. [CrossRef]

83. Kuby, M.; Wentz, E.A.; Vogt, B.J.; Virden, R. Experiences in developing a tourism web site for hiking Arizona's highest summits and deepest canyons. Tour. Geogr. 2001, 3, 454-473. [CrossRef]

84. Apollo, M.; Mostowska, J.; Maciuk, K.; Wengel, Y.; Jones, T.E.; Cheer, J.M. Peak-bagging and cartographic misrepresentations: A call to correction. Curr. Issues Tour. 2020, 1-6. [CrossRef]

85. Mutana, S.; Mukwada, G. Mountain-route tourism and sustainability. A discourse analysis of literature and possible future research. J. Outdoor Recreat. Tour. 2018, 24, 59-65. [CrossRef]

Publisher's Note: MDPI stays neutral with regard to jurisdictional claims in published maps and institutional affiliations.

(C) 2020 by the authors. Licensee MDPI, Basel, Switzerland. This article is an open access article distributed under the terms and conditions of the Creative Commons Attribution (CC BY) license (http://creativecommons.org/licenses/by/4.0/). 